\title{
In vitro digestibility of dockounou, a traditional plantain derivate dish of Côte d'Ivoire
}

\author{
Joseph Kouadio, Rose-Monde Megnanou, Eric Akpa, Severin Kra ${ }^{*}$, Sebastien Niamke \\ Laboratory of Biotechnology, UFR Biosciences, Félix Houphouët-Boigny University, 22 BP 582 Abidjan 22, Côte d'Ivoire
}

Email address:

kra_severin@yahoo.fr (S. Kra)

\section{To cite this article:}

Joseph Kouadio, Rose-Monde Megnanou, Eric Akpa, Severin Kra, Sebastien Niamke. In Vitro Digestibility of Dockounou, a Traditional Plantain Derivate Dish of Côte d'Ivoire. American Journal of BioScience. Vol. 2, No. 6, 2014, pp. 211-216. doi: 10.11648/j.ajbio.20140206.14

\begin{abstract}
The aim of this study was to identify sugar products from dockounou digestion. Tests of digestibility on various dockounou using a digestive juice of young snails namly Archachatina ventricosa and experimental acid hydrolysis were used. The results had showed that boiled dockounou were more hydrolysis than the backed one. Specifically, the rice boiled dockounou was more hydrolyzed than the maize boiled dockounou. Both rice boiled an baked dockounou are more hydrolyzed than the maize dockounou did. The sugars liberated for rice backed dockounou range from 0 to $0.80 \mu$ mol thereby it's 0 to $2.40 \mu \mathrm{mol}$ for maize one. These results are significantly differents $(p \leq 0.05)$. Enzymatic or acid hydrolysis products of boiled and backed dockounou are only the glucose. The intensity of this reducing sugar liberation depends on the time. This information shows, in the whole, that dockounou is an energetic dishe for children neither for diabetics.
\end{abstract}

Keywords: Ripe Plantain, Traditional Dish, Maize Flour, Rice Flour, Hydrolysis

\section{Introduction}

Musa (plantain and bananas) is the first fruit crop and produced throughout the world. It constitutes an important staple food in many developing countries, especially in Africa [1]. The world production of bananas and plantains (and the other types of this fruit) is estimated at 88 million tons per year [2]. Of the numerous edible varieties, plantain account for $19 \%$ and in 2010 , its production was estimated at 8.462 .530 tons in West Africa [3]. Côte d'Ivoire produces an average of 1 510778 tons of plantain a year [4]. This production depends on a season marked by a period of abundance which goes from September to April, followed by a period of shortage which extends from May to August $[5,6]$. However, a major problem of plantain is that the fruits are highly perishable. At ambient tropical temperatures, plantain and banana have an average market life of 1 to 10 days [7]. Indeed, plantain accounts 35 to $100 \%$ of post-harvest losses [8], generally resulting from diseases (crown rot, anthracnose, cigar-end rot, finger rot etc.), predator attacks (insects, birds, etc), physiological disorders (finger drop, peel splitting and chilling injury), mechanical damages induced by handling and transportation (impact, pressure, vibration, etc.) and the natural maturation process $[9$, $10,11]$. The difficulties of plantains preservation make the fruits, while ripening at the ambient temperature, undergo depreciation and also qualitative and quantitative degradations along the distribution chain [12].

Nevertheless, several solutions were found to reduce the post-harvest losses; but fruit transformation into less perishable products (flours, ships, etc) is at far the most concrete of all, mainly as far as trading is concerned $[8,9,11]$. People have also invented several dishes (fried, boiled and roasted plantain, porridge, pounded plantain) using unripe and ripe plantain fruits $[13,14,15,16,17]$. One of these dishes, named "dockounou" in Côte d'Ivoire, involves senescent plantain pulp and can be considered as an interesting solution in reducing post-harvest losses [18]. "Dockounou" his traditional pancake prepared by cooking or baking a mixture of pounded ripe plantains and a cereal flour [19]. It's considered as a ready to eat foods because it can be immediately consumed on the point of sale [20]. The consumption of dockounou concerned all the Ivorian sectors of the society [21]. Therefore, the aim of this study is to identify mainly sugar products from dockounou digestion. It is hoped that the findings would be of benefit to diabetics specifically and consumers in generally. 


\section{Materials and Methods}

\subsection{Samples Collection and Preparation}

Per seller, three (03) different samples of maize and rice boiled "dockounou" (Figure 1) and three (03) others of baked "dockounou" (Figure 2) were purchased from retail markets in the city of Abidjan in March 2013 after exhaustive inventory of traditional producers and sellers. All samples were collected in sterile conditions, and were transported aseptically in an icebox $\left(4-6^{\circ} \mathrm{C}\right)$ to the laboratory for further analysis. Each type of collected samples were mixed together in a sterile mortar to constitute one unit sample of maize boiled "dockounou", rice boiled "dockounou", maize baked "dockounou" and one unit sample of rice baked "dockounou". They were pouted in freezer at $-18^{\circ} \mathrm{C}$ for preservation.

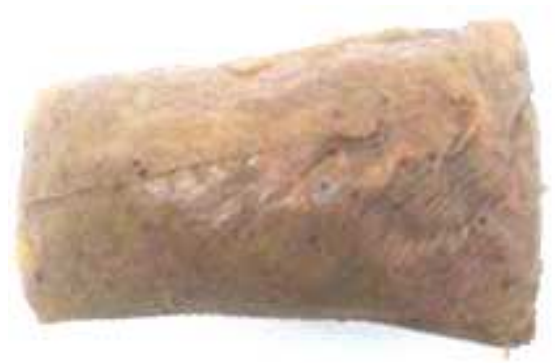

Figure 1. Boiled dockounou

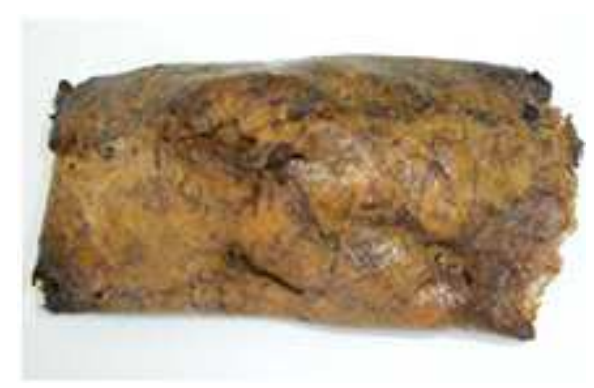

Figure 2. Backed dockounou

\subsection{Preparation of Substrate Solutions}

Fifty (50) grams of each type of dockounou sample were deleted in $200 \mathrm{~mL}$ of distilled water. After 30 minutes of decantation, the supernatant which content sugar reducing were eliminated. This operation is repeated several times to eliminate all reducing sugars. To verify that there is no reducing sugar, a test of [22] method was made on the last supernatant. In the same way, a thin-layer chromatography is made with the deposit according to [23] method.

The spot obtained was dried at $50^{\circ} \mathrm{C}$ for 24 hours in an etuve. The dry spot was reduced in powder in a mortar and for each sample, the substrate was prepared in $100 \mathrm{mM}(\mathrm{pH} 5.6)$ acetate buffer for enzymatic hydrolysis and in distilled water for acid hydrolysis.

\subsection{Enzymatic Extract Preparation}

Several young giant snails Archachatina ventricosa with a live weight of $30-40 \mathrm{~g}$ were gathered from the botanic garden of the Félix Houphouët-Boigny university. They have been abandoned without feed during three days. Each snail was killed according to [23] method and his mucous collected according to [24]. The mucous was filtered with gaze (a medical sterile compress). The filtrate obtained was separated in several aliquots of $1 \mathrm{~mL}$ and preserved in freezer at $-18^{\circ} \mathrm{C}$. Many dilutions of each aliquot for digestibility tests were made to find the adequate initial rate conditions for the experimental. So, the $1 / 150$ dilution was retained for the various enzymatic tests.

\subsection{Proteins of Brut Enzymatic Extract Test}

Proteins content in the brut enzymatic extract was determined according to [25] method using Folin-Ciocalteu reagent.

\subsection{In Vitro Enzymatic Hydrolysis}

In vitro enzymatic digestibility was performed during 24 hours with $200 \mu \mathrm{L}$ of reactional medium which content respectively: $100 \mu \mathrm{L}$ of acetate buffer (100 mM, pH 5.6), 80 $\mu \mathrm{L}$ of the substrate and $20 \mu \mathrm{L}$ of enzymatic extract diluted solution. The reactional medium was incubated at $37^{\circ} \mathrm{C}$ for 24 hours. At each intermediate time (1h, 2h, 4h, 8h, 12h, 16h, 20h and $24 \mathrm{~h}$ ), an aliquot of $100 \mu \mathrm{L}$ was taken to reducing sugar quantity test and 5 others $\mu \mathrm{L}$ were used in thin layer chromatography according to [23] method to identify the sugars which were appeared.

\subsection{Acid Hydrolysis}

It was realized with the chloridric acid $2.2 \mathrm{~N}$ during seven weeks. One (01) \% of substrate solution was diluted in chloridric acid solution $4.4 \mathrm{~N}$ initial concentration to obtained final concentration $2.2 \mathrm{~N}$ in $200 \mu \mathrm{L}$ of solution. This reactional medium was incubated at ambient temperature $\left(25^{\circ} \mathrm{C}\right)$ during 49 days. Every week, an aliquot of $100 \mu \mathrm{L}$ was test to quantify reducing sugar content and 5 others $\mu \mathrm{L}$ were taken to identify the sugar types appeared on thin layer chromatography according to [23] method.

\subsection{Statistical Analysis}

Each sample was analyzed in triplicate and data were reported as means. Differences between means were performed by analysis of variance (one way ANOVA) using StatPlus 2008 (Analystsoft Inc) software. Statistical significance was stated at $\mathrm{p} \leq 0.05$.

\section{Results}

\subsection{Enzymatic Hydrolysis}

"Fig.3" presents the evolution of reducing sugars quantity liberated in time during the enzymatic hydrolysis. The kinetic of this hydrolysis shows, in the whole that, the boiled dockounou were more hydrolysis than the backed one. Specifically, the rice boiled dockounou was more hydrolyzed than the maize boiled dockounou. Values obtained for the both 
dockounou are significantly differents $(p \leq 0.05)$. Indeed, total sugars liberated range from 0 to $5.10 \mu \mathrm{mol}$ in 12 hours for rice boiled dockounou then its ranged from 0 to $4.74 \mu \mathrm{mol}$ for maize one. After the $14^{\text {th }}$ hour, the inverse situation was observed. Maize boiled dockounou liberate more sugars (5.14 to 5.70 $\mu \mathrm{mol})$ than the rice boiled dockounou ( 5.16 to $5.56 \mu \mathrm{mol}$ ).

Both boiled an baked dockounou are more hydrolyzed than the maize dockounou did. The sugars liberated for rice backed dockounou range from 0 to $0.80 \mu \mathrm{mol}$ however it's 0 to 2.40 $\mu \mathrm{mol}$ for maize one. These results are significantly differents $(\mathrm{p} \leq 0.05)$. This hydrolysis is very important for the rice baked dockounou up to the $12^{\text {th }}$ hour, while it's linearly for maize one's up to the $24^{\text {th }}$ hour.

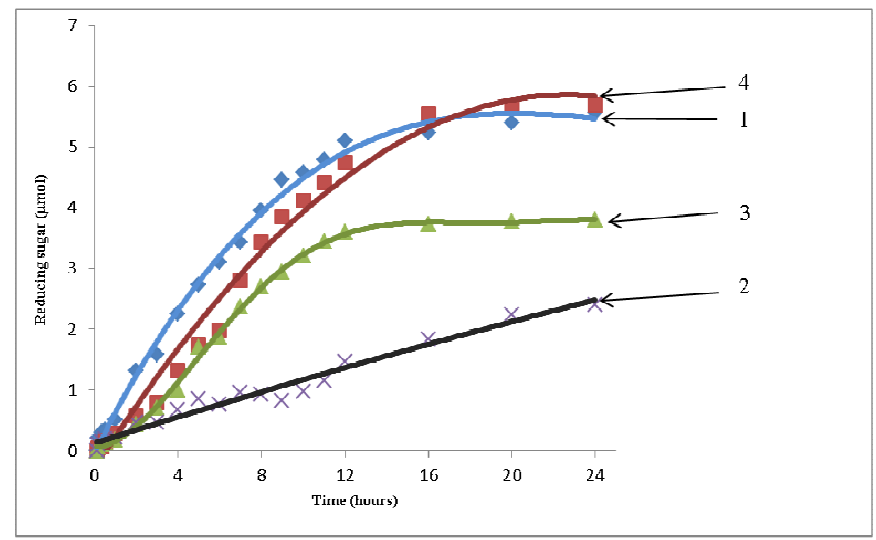

Figure 3. Kinetics hydrolysis curves of products stemming from enzymatic hydrolysis of various types of dockounou.

1: rice boiled dockounou ; 2 : maize backed dockounou; 3 : rice backed dockounou; 4: maize boiled dockounou

The results had permitted to determinate the different initial rate values of the kinetic enzymatic hydrolysis. In table 1, were reported these values which varied according dockounou and are significantly differents at $\mathrm{p} \leq 0.05$ with the three others. Indeed, the initial rate of hydrolysis value of rice boiled dockounou (9.97 $10^{-3} \mathrm{UI} / \mathrm{mg}$ of proteins) are the more highest than the three others dockounou's which were respectively $3.3810^{-3} \mathrm{UI} / \mathrm{mg}$ of proteins for maize boiled dockounou, 3.31 $10^{-3} \mathrm{UI} / \mathrm{mg}$ of proteins for rice baked dockounou and $2.810^{-3}$ $\mathrm{UI} / \mathrm{mg}$ of proteins for maize baked dockounou and are not significantly different ( $\mathrm{p} \geq 0.05$ ).

Enzymatic profile was shown by Figure 4. The results showed that it was appeared on the chromatogram only reducing sugars which had the same molecular weight as the glucose. The intensity of this appearing depends on the time. Indeed, it's more important as the time increase.

Table 1. Initial rate of enzymatic hydrolysis of various types of dockounou.

\begin{tabular}{ll}
\hline Types of dockounou & Initial rate (UI/mg of proteins) \\
\hline Rice boiled dockounou & $9.9710^{-3} \pm 0.85^{\mathbf{a}}$ \\
Maize boiled dockounou & $3.3110^{-3} \pm 0.97^{\mathbf{b}}$ \\
Rice backed dockounou & $2.8010^{-3} \pm 0.45^{\mathbf{b}}$ \\
Maize backed dockounou & $3.3810^{-3} \pm 0.97^{\mathbf{b}}$ \\
\hline
\end{tabular}

Means followed by different letters ( $a$ or b) are significantly differents at $\mathrm{p} \leq 0.05$
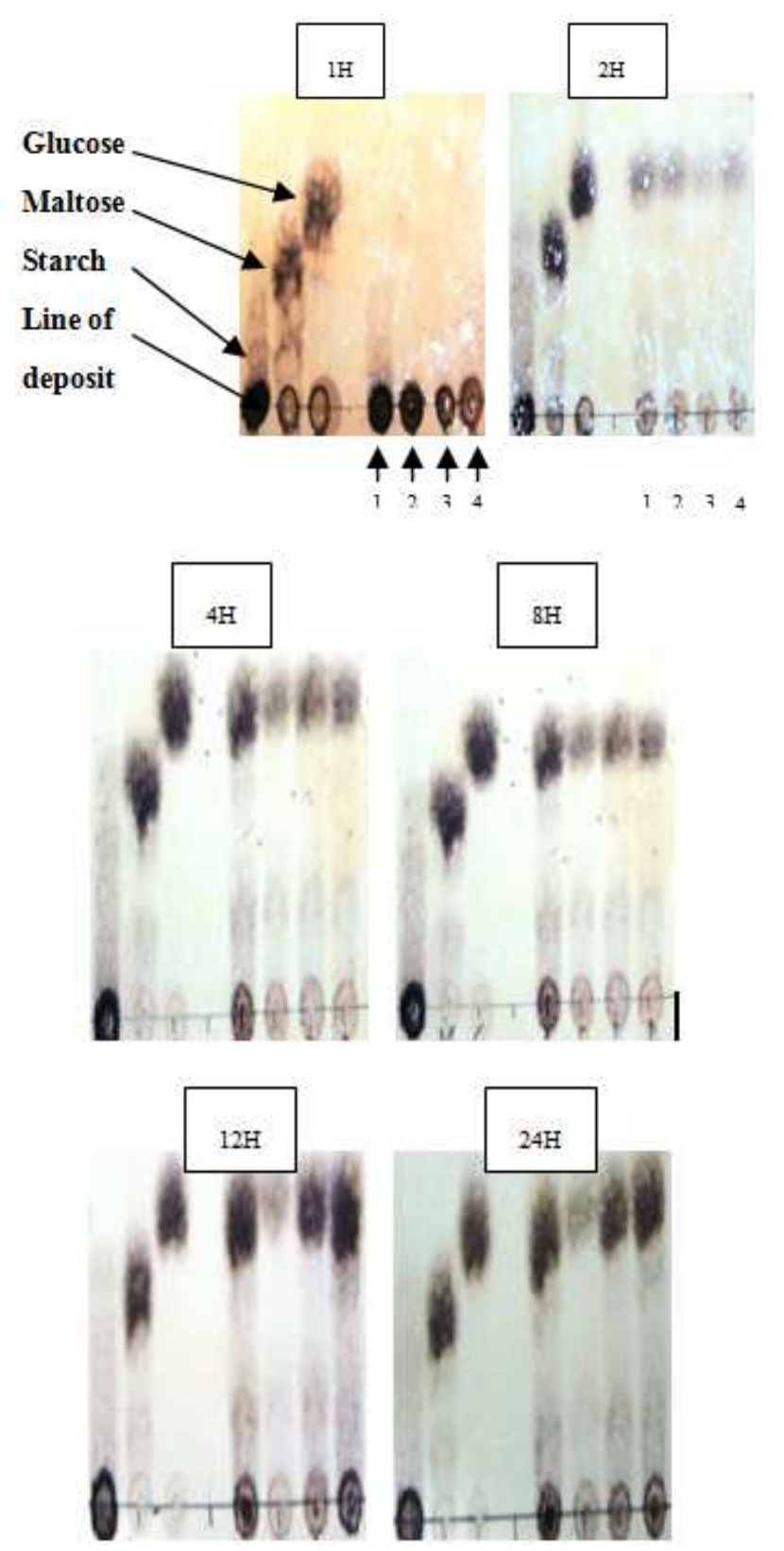

Figure 4. Enzymatic hydrolysat thin layer chromatographic profile of various types of dockounou.

1: rice boiled dockounou ; 2: maize backed dockounou; 3 : rice backed dockounou ; 4: maize boiled dockounou

\subsection{Acid Hydrolysis}

During all the experimental, reducing sugars liberated by acid hydrolysis of rice boiled dockounou are more importants than the others; whatever, those for rice baked dockounou are the lowest (Figure 5). Until the $21^{\text {th }}$ day, it observed an important increase quantity of reducing sugars from rice and maize boiled dockounou (ranged from 0 to 0.85 and 0 to 0.59 $\mu$ mol respectively and statisticaly differents $(\mathrm{p} \leq 0.05))$ and maize baked dockounou ranged from 0 to $0.55 \mu \mathrm{mol}$. After this day, the increase is relatively weak up to the $35^{\text {th }}$ day (ranged from 0.85 to $0.88 ; 0.6$ to 0.73 and 0.55 to $0.63 \mu \mathrm{mol}$ respectevely). 
The initial rate values of the acid hydrolysis which were determined through the graphics were consigned in table 2 . These values are significantly differents at $\mathrm{p} \leq 0.05$ and revealed that the boiled dockounou are the more highest initial rate values $\left(16.3010^{-6}\right.$ and $8.9010^{-6} \mathrm{UI} / \mathrm{mL}$ of $\mathrm{HCl}$ for maize and rice dockounou respectively which are statisticatly differents at $\mathrm{p} \leq 0.05)$ than the baked dockounou $\left(2.0810^{-6}\right.$ and $3.7110^{-6} \mathrm{UI} / \mathrm{mL}$ of $\mathrm{HCl}$ for maize and rice dockounou respectively wich are not significantly differents at $\mathrm{p} \geq 0.05$ ).

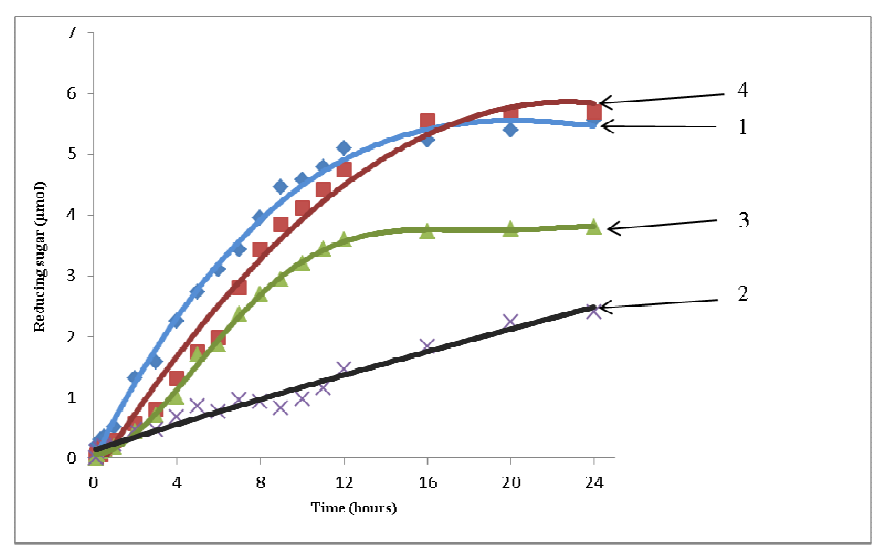

Figure 5. Kinetics hydrolysis curves of products stemming from acid hydrolysis of various types of dockounou.

1: rice boiled dockounou ; 2 : maize backed dockounou; 3 : rice backed dockounou ; 4: maize boiled dockounou

Table 2. Initial rate of acid hydrolysis of various types of dockounou.

\begin{tabular}{ll}
\hline Types of dockounou & Initial rate (UI/mL of HCI 2.2N) \\
\hline Rice boiled dockounou & $8.9010^{-6} \pm 0.96^{\mathbf{b}}$ \\
Maize boiled dockounou & $16.3010^{-6} \pm 1.08^{\mathbf{a}}$ \\
Rice backed dockounou & $3.7110^{-6} \pm 0.70^{\mathbf{c}}$ \\
Maize backed dockounou & $2.0810^{-6} \pm 0.37^{\mathbf{d}}$ \\
\hline
\end{tabular}

Means followed by different letters (a, b, c, d) are significantly differents at $\mathrm{p} \leq 0.05$

\section{Discussion}

The study had revealed that products of the enzymatic or acid hydrolysis of boiled and backed dockounou are only glucose as reducing sugar. The intensity of the spots of glucose obtained on the various chromatographic patches varied according to the duration of the hydrolysis. What confirms the speed of the curves of the kinetics of hydrolysis. The obtained sugar would result from insoluble fibers and the other glucidic constituents especially that free sugars were eliminated by the wash. Indeed, the content of ripe banana crude fiber range from 0.58 to $1.21 \%[26,27,28]$; for baked products, the insoluble fiber ranged from 0.89 to $8.64 \%$ [26]. Also, some authors $[29,30]$ pointed out that the dietary fiber yields in flours were not affected by the heating like wise stage of plantain maturation. These assertions showed effectively that the glucose which was released after hydrolyze is from insoluble fiber and other carbohydrates not soluble in water. The Life Sciences Research Office of the
Federation of American Societies for Experimental Biology defines fiber as "the endogenous components of plant materials in the diet which are resistant to digestion by enzymes produced by humans. Simply put, dietary fiber, including cellulose, hemicelluloses, pectin, and lignin, comes from the cell walls of plants plus other indigestible components of plants [31]. But, it is well known that fiber as cell wall content, can be digested by among animals like snail. Indeed, according to [32], snail digestive juice is known to be a complex mixture of enzymes and also, many reports indicated the presence of hydrolyzing enzymes in the digestive juice of snail [33]. Also, according to [34], other author products of the action of snail juice fractions on some Yeast cell-walls are glucose and mannose which can be detectable. These reports were confirmed by the acid hydrolysis. The same authors are reported that digestive juice of snail content abundant carbohydrases like exo-amylases and $\alpha$-glucosidase activities [35,36]. The snail digestive juice action had showed that the boiled dockounou were more digestible than those for backed. This fact is confirmed by the initial rates obtained, in the both hydrolysis, for all sample which are higher for boiled dockounou than the backed one. This can be explained by the hydro-thermic treatment used, which probably modify enzymes affinity for his substrates content in the food. Indeed, according to a report [37], there is respectively an earning and a loss of humidity in the processes of cooking with water and with the oven. In fact, during the boiled process, water and heat favors the gelatinization of carbohydrates contained in rice and corn. This hydro-thermic treatment pulls the disorganization of the structure of carbohydrates [38, 39]. According to another report [39] the water and the heat swells gradually entailing an increase of the surface of available attack of glucidic constituents (starch, amylose, amylopectin). All these structural modifications are going to favor the hydrolysis by the enzymatic raw extract.

Concerning baked dockounou, the dry heat treatment dehydrates glucidic constituents. This loss of water would strengthen the crystalline phases of the granules of carbohydrates. What would prevent the restructuring and the relaxation of constituents and thus their complete gelatinization which doesn't facilitates the hydrolysis action of enzymes.

The results are showed that whatever the mode of cooking, dockounou prepared with the ground rice are more easily hydrolyzed than dockounou prepared with the corn starches. This can be explaining by the size of grains of the starch, the presence of micro-pore on their surface, the degree of physical damage and the content in amylose grains of starch [40, 41, 42]. Moreover, some authors [43] are reported that the rice mush flour is more hydrolysis than the maize flour mush. They are showed that the digestion rate of rice is better than the maize one. Also, other authors [36] are reported that the variability of the starch grain size could influence the enzymatic attack considerably. This shows that glucidic chain in rice, after the digestion, would liberate rapidly more sugars than the maize did. 
Besides the weak, rate of hydrolysis of backed dockounou beyond 24 hours of enzymatic hydrolysis shows that carbohydrates stemming from these preparations are resistant in enzymes. These glucidic constituents could present beneficial effects at the level of the colon. Indeed, these slowly digestible carbohydrates could behave as fibers in the bowel. What would favor the increase of the production of saddles, the stimulation of the fermentation stomach pain, the decrease of the cholesterol level on an empty stomach and the decrease of the glycaemia.

\section{Conclusion}

The digestibility tests using enzymatic or acid hydrolysis are shown in the whole that the various dockounou studied liberate glucose as the most important reducing sugar from these hydrolysis. This sugar would result from insoluble fibers and the other insoluble glucidic constituents in the dockounou. These results permit to recommend the dockounou to African young boy or children who need more energetic resources to growth however it recommend to diabetic to pay more attention for these dishes.

\section{References}

[1] IITA (2012). Improving plantain and banana based. IITA, Ibadan. p. 67.

[2] Bakry F., Didier C., Ganry J., Le-Bellec F., Lescot T., Pi non A., Rey JY., Teisson C. and Vannicre M. (2002). Fruits species. In: Guide of agronomist CIRAD, Paris. pp. 960-974.

[3] FAOSTAT (2012). Food and Agricultural Organiza tion, Agricultural Data. Crops and products domain. http://faostat.fao.org/site/339/default.aspx Rome, Italy. March 09, 2014.

[4] FAO (2008). Le manioc pour la sécurité alimentaire et énergétique, investor dans la recherché pour en ac croître les rendements et les utilisations. FAO salle de presse,Juillet2008,Rome(Italie),http://www.fao.org/ne wsroom/fr/news/2008/1000899/index.h tml. August 22, 2012.

[5] Kuperminc O. (1985). Saisonnalité de commercialisa tion de la banane plantain en Côte d'Ivoire. Fruits. 43 :359-368.

[6] Sery D. G. (1988). Rôle de la banane plantain dans l'écono mie Ivoirienne. Fruits. 43(2): p.73-78.

[7] Zakpaa H., Mak-mensah E. and Adubofour J. (2010). Production and characterization of flour produced from ripe «Apem» plantain (Musa sapientum L. var. paradisiacal; French horn) grown in Ghana. J. Agri. Bi otech. Sust. Develop. 2: 92-99.

[8] Atanda SA., Pessu PO., Agoda S., Isong IU. and Ikotun I. (2011). The concepts and problems of post-harvest food losses in perishable crops. Afr. J. Food Sci. 5(11): 603-613.

[9] Dadzie B. and Orchard J. (1997). Routine Post-Harvest Screening of banana/Plantain Hy brids: Criteria and Meth ods. Inibap Technical Guide lines, $75 \mathrm{p}$.

[10] Tchango-Tchango J., Bikoï A., Achard R., Escalant JV. and
Ngalani JA. (1999) Plantain: Post harvest opera tions. Mejia D, Lewis B (eds) AGSI/FAO, 59. March 28, 2013.

[11] Emaga H., Andrianaivo, Wathelet B., Tchango T., Paquot M. (2007). Effects of the stage of maturation and varieties on the chemical composition of banana and plantain peels. Food Chem. 103: 590-600.

[12] Chia CL., Huggins CA. (2003). Bananas. In: CTAHR (ed). Community fact sheet fruit. Ha waii. pp. 23-29.

[13] Camara C. (1984). Les cultures vivrières en Répu blique de Côte d'Ivoire. Ann. Géog. 92 (518): 432-453. http://dx.doi.org/10.3406/geo.1984.20279.

[14] Dzomeku B., Osei-Owusu M., Akyeampong E., Ankoma A. and Darkey. S. (2005). Sensory evalua tion of some hybrid cooking bananas in Ghana. Afr. Crop. Sci. Conf. Proc. 7: 631-633.

[15] Koffi K. (2007). Rôle des ressources génétiques dans l'essor du secteur bananier plantain en Côte d'Ivoire. In: Plant genetic resources and food security in West and Central Africa. Regional Conference, Ibadan, Nigeria, 26-30 April, 2004-2007. Vodouche R, At ta-Krah K, Achigan-daka GE, Eyog-Matig (eds). $365 \mathrm{p}$.

[16] Dzomeku BM., Dankyi AA. and Darkey SK. (2011). Socio economic importance of plantain cultivation in Ghana. J. Ani. Plant Sci. 2: 269-273.

[17] Honfo FG., Tenkouano A. and Coulibaly O. (2011). Banana plantain-based foods consumption by chilren and mothers in Cameroon and Southern Nigeria: A comparative study. Afr. J. Food Sci. 5: 287-291.

[18] Akoa E., Kra K., Megnanou R-M., Akpa E. and Ahonzo N. (2012). Sensoriel characteristics of se nescent plan tain empiric disch (Dockounou) produced in Côte d'Ivoire. J. Food Res. 1: 150-159.

[19] Mégnanou R-M., Kra KAS., Zoué L., Akoa E., Yéboué K. and Niamké LS. (2013). Microbiologi cal safety and quality assessment of a very appre ciate traditional ready to eat plantain food, sold in retails markets. Afr. J. Micro. Res. 7(32): p. 4123-4129 DOI: 10.5897/AJMR12.1282.

[20] Tsang D. (2002). Microbiological guidelines for ready to eat food. Environmental Hygiene Department. Hong Kong. pp.115-116. Vasut RG, Robeci MD (2009). Food contamination with psychrophilic bacteria. Med. Vet. 2 : 325-330.

[21] Kra AS., Akoa E, Megnanou R-M., Yeboue K., Akpa EE. and Niamke LS. (2012). Physicochemical and nutri- tional characteristics assessement of two different trade tional foods prepared with senescent plantain. Afr. J. Food Sc. 7 (3): p.51-55.

[22] Bernfeld D. (1956). Amylase $\beta$ et $\alpha$, In : method in enzymology 1, Colowick S.P. and Kaplan N.O., Academic Press. pp 149-154.

[23] Boussarsar H., Roge B., Mathlouthi M. (2007). Physi co-chemical Approach of the Amylolytic Action Pattern of a Thermostable Amylopullulanase Food Biophysics, 2: 100-107.

[24] Lee MK., Moon JH. and Ryu HS. (1994). Nutrient compo sition and protein quality of giant snail product. J. Korean Soc. Food Nutr. 23: 453-458. 
[25] Lowry OH., Rosebrough NJ., Farra L. and Randall RJ. (1951). J. Biol. Chem. 193: 265-275.

[26] Betty WL., Karen W., Andrew SW. and Pamela RP. (2002). Individual Sugars, Soluble, and Insoluble Dietary Fiber Contents of 70 High Consumption. Foods. J. Food Comp. Anal. 15: 715-723 doi:10.1006/jfca.2002.1096.

[27] Egbebi AO, Bademosi TA. (2012). Chemical composi tions of ripe and unripe banana and plaintain. Int. J. Trop. Med. Public Health. 1(1): 1-5

[28] Erny JN., Nurali GSS., Djarkasi MFS. and Sumual EL. (2012). The potential of goroho plantain as a source of functional food. tropical plant curriculum (tpc) pro ject in cooperation with USAID - TEXAS A\&M UNIVERSITY - SAM RATULANGI UNIVER SITY, $23 \mathrm{p}$.

[29] Gwanfogbe PN., Cherry JP., Simmons JG., James C. (1988). Functionality and nutritive value of composite plan tain (Musa paradisiaca) fruit and glandless cotton seed flours. Tropic. Sci. 28: 51-66.

[30] Emagaa TH., Christelle R.a, Sébastien NR., Bernard W. and Michel P. (2008). Dietary fibre components and pectin chemical features of peels during ripening in banana and plantain varieties. Bior. 99(10):4346-4354.DOI:10.1016/j.biortech. 2007.08.030

[31] Linda VH. (1997). Fiber, Lipids, and Coronary Heart Disease; A Statement for Healthcare Professionals from the Nutrition Committee, American Heart Association. Circu lation.

[32] Holden M. and Tracey MV. (1950). A study of enzymes that can break down tobacco-leaf compo nents. 4. Mamma lian pancreatic and salivary enzymes. Bioch. J. 47(4): 421-425.

[33] Colas B. and Attias J. (1977). Purification of two beta glycosidases of digestive juice of Achatina bateata. Bioch. 59, 577-585.

[34] Myers F. L. and Northcote D. H. (1958). Partial Puri fication and some Properties of a Cellulase from Helix pomatia. Department of BiocheMistry, University of Cambridge. Vol. 71: 749-756.
[35] Saki SJ., Sea TB., Koffi KM., Soro YR., KRA KAS. and Diopoh KJ. (2013). Purification and physicochemical characterization of the $\alpha$-glucosidase of the digestive juice of the snail Limicolria flammea (Müller 1774). Int. J. Plant An. Env. Sci. 4 (1): 376-388.

[36] Sea TB., Saki SJ., Koffi KM., Soro YR., Trébissou JDN., Otchoumou A. and Diopoh KJ. (2013). Action of the digestive juice of the snail Limicolaria flammea on raw starches. Int. J. Appl. Biol. Phar. Tech. 4 (4): 114-119.

[37] Ahenkora KM., Kye A., Marfo K. and Banful B. (1997). Nutritional composition of false horn Apantupa plantain during ripening and processing. Afr. Crop Sci. J. 5: 243-248.

[38] Colonna P., Melcion JP. and Mercier C. (1976). Influence de l'irradiation infrarouge et de l'aplatissage sur fragmentation, la composition du maïs et sur l'état de son amidon. Ann. Tech. Agri. 25: 291-308.

[39] Mercier C. (1979). Effects of various US grain process on the alteration and the in vitro digestibility of starch granule. Feedstuffs. 43: 33-47.

[40] French D. (1984). Organisation of starch granules. In: Whistler R.L., Bemiller J.N. and Paschall E.F., eds. Starch: chemistry and technology. 2nd ed. New York, USA: Academic Press Inc.

[41] Fannon J.E., Hauber R.J. and BeMiller J.N. (1992). Surface pores of starch granules. Cereal Chem. J. 69: 284-288.

[42] Dona A.C., Pages G., Gilbert R.G. and Kuchel P.W. (2010). Digestion of starch: In vivo and in vitro kinetic models used to characterize oligosaccharide or glucose re lease. Carbohydrate Polymer. 80: 599-617.

[43] Brou K., Gbogouri A., Ocho AL., Djéni NT., Koné Y. and Gnakri D. (2008). Assessment of some chem ical and nutritional properties of maize, rice and millet grains and their weaning mushes. Pakistan J. Nutr. 7 (6): 721-725. 